\title{
French Arthurian Romance, Vol. III: Le Chevalier as deus espees, Edited and Translated by Paul Vincent Rockwell
}

\section{G. Matteo Roccati}

\section{(2) OpenEdition}

Journals

Édition électronique

URL : http://journals.openedition.org/studifrancesi/6184

DOI : 10.4000/studifrancesi.6184

ISSN : 2421-5856

Éditeur

Rosenberg \& Sellier

Édition imprimée

Date de publication : 1 novembre 2010

Pagination : 526

ISSN : 0039-2944

\section{Référence électronique}

G. Matteo Roccati, «French Arthurian Romance, Vol. III: Le Chevalier as deus espees, Edited and Translated by Paul Vincent Rockwell », Studi Francesi [En ligne], 162 (LIV | III) | 2010, mis en ligne le 30 novembre 2015, consulté le 09 janvier 2021. URL : http://journals.openedition.org/studifrancesi/6184 ; DOI : https://doi.org/10.4000/studifrancesi.6184

Ce document a été généré automatiquement le 9 janvier 2021.

\section{cc) (†) $\odot$}

Studi Francesi è distribuita con Licenza Creative Commons Attribuzione - Non commerciale - Non opere derivate 4.0 Internazionale. 


\title{
French Arthurian Romance, Vol. III: Le Chevalier as deus espees, Edited and Translated by Paul Vincent Rockwell
}

\author{
G. Matteo Roccati
}

\section{RÉFÉRENCE}

French Arthurian Romance, Vol. III: Le Chevalier as deus espees, Edited and Translated by Paul Vincent RocKWELL, Cambridge, D.S. Brewer, 2006 («Arthurian Archives», XIII), pp. VIII-648.

1 Le Chevalier as deus espees (parfois désigné aussi Meriadeuc) est un roman anonyme de 12360 octosyllabes environ, conservé dans un manuscrit unique: Paris, BnF, fr. 12603. Il a été composé en Angleterre entre 1210 et 1235 et émane vraisemblablement du milieu des barons ayant quitté le continent à la suite des conquêtes de Philippe Auguste. L'introduction présente le roman, discute la datation et traite des différents points qui font son intérêt: le thème des deux épées, celui de la continuité historique et familiale, les références implicites aux romans de Chrétien et leur dimension parodique. Elle se termine par l'étude de la scripta (picarde) du manuscrit.

2 Edition conservative (contrairement à la première édition par W. Foerster, 1877) avec traduction anglaise en regard (en appendice la liste des vers hypomètres et hypermètres), notes (pp. 613-635), bibliographie et index. 